\title{
PENATAAN HUNIAN KUMUH PERKOTAAN \\ DI ATAS TANAH ULAYAT: \\ STUDI KASUS PADA KOTA PAYAKUMBUH, SUMATERA BARAT
}

\author{
Noegi Noegroho \\ Architecture Department, Faculty of Engineering, Binus University \\ Jl. K. H. Syahdan No. 9, Palmerah, Jakarta Barat 11480 \\ noeginoegroho@gmail.com
}

\begin{abstract}
Slum areas are likely found in many cities in Indonesia although the government through the Ministry of Public Housing have rolled several programs to alleviate its existence. One example of slum areas is found in Payakumbuh, West Sumatra, where its land are mostly owned by local traditional folks knowned as 'ulayat land'. A huge amount of poor houses are built on rented ulayat land. Regarding to the rent status, the housing arrangement on the area faces difficulties. Therefore, this article would like to give an overview of problems in the slums arrangement in Payakumbuh as well as giving some concepts for dealing with the problems associated with such land status owned by adat.
\end{abstract}

Keywords: slums arrangement, ulayat land, rented land, traditional folks

\begin{abstract}
ABSTRAK
Hunian kumuh masih kerap dijumpai di banyak kota di Indonesia meski pemerintah melalui Kementerian Negara Perumahan Rakyat telah menggulirkan beberapa program untuk mengentaskan keberadaannya. Salah satu contoh hunian kumuh ditemui di Payakumbuh, Sumatera Barat, dimana hampir semua tanahnya dimiliki oleh masyarakat adat atau yang dikenal dengan tanah ulayat. Banyak hunian tidak layak berdiri di atas tanah ulayat sewaan. Mengingat status tanah tersebut, penataan rumah di kota ini mengalami kesulitan. Oleh karena itu, artikel ini dibuat untuk memberikan gambaran permasalahan dalam penataan kawasan kumuh di Payakumbuh, sekaligus memberi konsep bagaimana solusi penanganannya terkait dengan status kepemilikannya sebagai tanah ulayat.
\end{abstract}

Kata kunci: penataan hunian kumuh, tanah ulayat, tanah sewaan, masyarakat adat Sumatra Barat 


\section{PENDAHULUAN}

Hunian kumuh sudah umum ditemukan di kota-kota di Indonesia. Keberadaannya merupakan wujud tarik menarik antara ketersediaan hunian perkotaan yang terbatas dan perkembangan kegiatan kota yang 'menarik' bagi masyarakat untuk hidup di kota. Alhasil hunian kumuh pun muncul sebagai jawaban masyarakat untuk bisa di wilayah perkotaan sesuai dengan kemampuannya. Kumuh, menurut Adisasimita (2010) diartikan sebagai permukiman atau perumahan orang-orang miskin kota yang berpenduduk padat. Umumnya kawasan ini jorok dan dengannya melekat pula ciri kehidupan sosial penghuninya yang bertaraf rendah. Soehendera (2010) mengutip Suparlan di dalam bukunya, ciri-ciri permukiman kumuh antara lain kondisinya kurang atau tidak memadai, fasilitas kondisi hunian rumah dan permukiman serta penggunaan ruang-ruangnya mencerminkan penghuninya yang kurang mampu atau miskin.

Sama halnya kota-kota lain di Indonesia, kota-kota di Sumatera Barat pun tidak terlepas dari masalah keberadaan hunian kumuh di beberapa bagian dalam wilayah kotanya, terutama di pusat kota. Hunian kumuh yang ditandai dengan kualitas lingkungan yang rendah dan kondisi rumah-rumah yang memprihatinkan baik ditinjau dari aspek fungsi, kesehatan dan kenyamanan. Pemerintah melalui program-program yang ada berusaha untuk menghilangkan keberadaan rumah kumuh tersebut dengan memberikan bantuan pembangunan PSU (Prasarana Sarana Umum) dan perbaikan rumah-rumah kumuh dalam wadah penataan kawasan. Hanya saja penataan kawasan di wilayah Sumatera Barat memang memiliki kekhasan sendiri karena tanah dimana hunian kumuh tersebut berada berstatus tanah adat/ulayat.

Tulisan ini merupakan pengalaman penulis yang terlibat dalam program pemerintah dalam penanganan hunian kumuh yang berlokasi di Kelurahan Kotabaru Balaijanggo, Payakumbuh, Sumatera Barat.

\section{Pemerintah dan Program Penataan Hunian Kumuh}

Melihat kondisi hunian kumuh di Indonesia, pemerintah berusaha mengurangi keberadaannya melalui berbagai program. Sejak tahun 2004, pemerintah pusat dalam hal ini Kementerian Perumahan Rakyat telah menggulirkan beberapa program untuk peningkatan kualitas lingkungan perumahan terutama bagi Masyarakat Berpenghasilan Rendah (MBR). Beberapa program tersebut antara lain: Bantuan Stimulan Bangunan Perumahan Swadaya (BSP2S) dan Peningkatan Kualitas Perumahan (PKP), Pembangunan Rusunawa dan Rusunami, Bantuan Stimulan Prasarana Sarana Umum (PSU) Perumahan, dan Permukiman dan Penyaluran KPRS Mikro bersubsidi. Sejak tahun 2010, Kemenpera menggulirkan program Penanganan Lingkungan Perumahan dan Permukiman Kumuh Berbasis Kawasan (PLP2K-BK) dengan focus untuk: (1) mengembangkan kawasan perumahan dan permukiman terintegrasi dengan tata ruang dan sistem kota; (2) menggunakan pendekatan tridaya (manusia, lingkungan dan ekonomi); (3) melengkapi kebutuhan PSU agar terpenuhi lingkungan yang layak; dan (4) mengintegrasikan pendekatan sektor dan pelaku lainnya.

Melihat beberapa program tersebut, sesungguhnya apa saja yang ditangani? Sesuai UU no 4 tahun 1992 pasal 27, pada dasarnya lingkup penanganan lingkungan permukiman kumuh mencakup beberapa hal berikut: (1) perbaikan dan pemugaran; (2) peremajaan; (3) pengelolaan dan pemeliharaan berkelanjutan.

\section{Perbaikan dan Pemugaran}

Secara konseptual, implementasi prinsip perbaikan dan pemugaran meliputi tindakan-tindakan dalam kerangka: (1) revitalisasi, yaitu upaya menghidupkan kembali suatu kawasan 'mati' yang pada 
masa silam pernah hidup, atau mengendalikan dan mengembangkan kawasan untuk menemukan kembali potensi yang dimiliki atau pernah dimiliki atau seharusnya dimiliki oleh sebuah kota; (2) rehabilitasi, yaitu upaya mengembalikan kondisi komponen fisik lingkungan permukiman yang mengalami degradasi; (3) renovasi, yaitu melakukan perubahan atas sebagian atau beberapa bagian dari komponen pembentukan lingkungan permukiman; (4) rekonstruksi, yaitu upaya mengembalikan suatu lingkungan permukiman sedekat mungkin dari asalnya yang diketahui dengan menggunakan komponen-komponen baru maupun lama; (5) preservasi, yaitu upaya mempertahankan suatu lingkungan permukiman dari penurunan kualitas atas kerusakan. Penanganan ini bertujuan untuk memelihara komponen yang berfungsi baik dan mencegah dari penyusutan dini (kerusakan), misalnya dengan menggunakan instrumen Ijin Mendirikan Bangunan (IMB) dan ketentuan atau pengaturan tentang koefisien lantai bangunan, koefisien dasar bangunan, garis sempadan bangunan, garis sempadan jalan, garis sempadan sungai dan lain sebagainya.

\section{Peremajaan}

Peremajaan adalah upaya pembongkaran sebagian atau keseluruhan lingkungan perumahan dan permukiman dan kemudian di tempat yang sama dibangun prasarana dan sarana lingkungan perumahan dan permukiman baru yang lebih layak dan sesuai dengan rencana tata ruang wilayah. Tujuan utama dari kegiatan ini adalah untuk meningkatkan nilai pemanfaatan lahan yang optimal sesuai dengan potensi lahannya. Di samping itu, diharapkan mampu memberikan nilai tambah secara ekonomi sdan memberi 'vitalitas' baru dari lahan permukiman yang diremajakan. Pada umumnya, peremajaan ini memberikan konsekuensi bentuk teknis penanganan seperti halnya: land consolidation, land re-adjustment dan land sharing.

\section{Pengelolaan dan Pemeliharaan Berkelanjutan}

Pengelolaan dan pemeliharaan berkelanjutan adalah upaya untuk mencegah, mengendalikan atau mengurangi dampak negatif yang timbul, serta meningkatkan dampak positif yang timbul terhadap lingkungan hunian.

Pada tahun 2011, beberapa kota di Indonesia menerima program penataan kawasan hunian kumuh ini, salah satunya adalah kota Payakumbuh (Propinsi Sumatera Barat). Program ini diharapkan dapat menghilangkan kekumuhan di beberapa bagian wilayah kota yaitu di kelurahan Kotabaru Balaijanggo. Wilayah tersebut berada di kawasan permukiman dekat dengan pusat kota di mana terdapat beberapa rumah tidak layak huni dengan kualitas lingkungan di sekitarnya yang kurang memadai.

\section{Profil Kota Payakumbuh}

Kota Payakumbuh berada dalam wilayah administrasi Propinsi Sumatera Barat, letaknya di sebelah Utara kota Padang. Kota Payakumbuh berjarak $125 \mathrm{~km}$ dari kota Padang, dapat ditempuh selama kurang lebih tiga jam dengan jalan darat melalui kota Bukittinggi. Kota ini juga dapat ditempuh dari Pekanbaru yang berjarak $188 \mathrm{~km}$ di sebelah Timurnya (Gambar 1). Menurut situs resmi Pemkot Payakumbuh, kota ini merupakan kota dua terbesar di Sumatera Barat (setelah kota Padang) dengan luas wilayah $80,43 \mathrm{~km}^{2}$. Kota Payakumbuh terdiri dari delapan nagari, lima kecamatan dan 76 kelurahan. Jumlah penduduk menurut pada tahun 2008 sebanyak 104.969 jiwa.

Secara geomorfologi, Kota Payakumbuh berada di dataran luas yang dikelilingi oleh perbukitan. Fungsi pertanian merupakan landuse yang cukup dominan di wilayah kota Payakumbuh ini didukung oleh beberapa sungai yang membelah kota dari arah utara ke selatan. 
Secara ekonomis, kota Payakumbuh merupakan pintu gerbang dari kota Pekanbaru menuju kota-kota di Sumatera Barat, menjadi pusat pemasaran dan sentra ekonomi bagi kabupaten disekitarnya seperti Kabupaten Limapuluh koto, Tanah Datar, Agam dan Kota Bukittinggi yang letaknya tidak jauh. Hal ini juga ditandai dengan keberadaan dua pasar yang cukup ramapi di pusat kota yaitu pasar Payakumbuh (pasar kering) dan pasar ibuah sebagai tempat memperjual belikan hasil bumi dan sayuran (pasar basah). Fungsi Perkantoran dan Jasa cukup menonjol di pusat kota, kehadiran Universitas Andalas dan beberapa fasilitas pendidikan dan kesehatan memperlihatkan kota Payakumbuh sebagai 'sentral peradaban' bagi daerah di sekitarnya (Gambar 2).

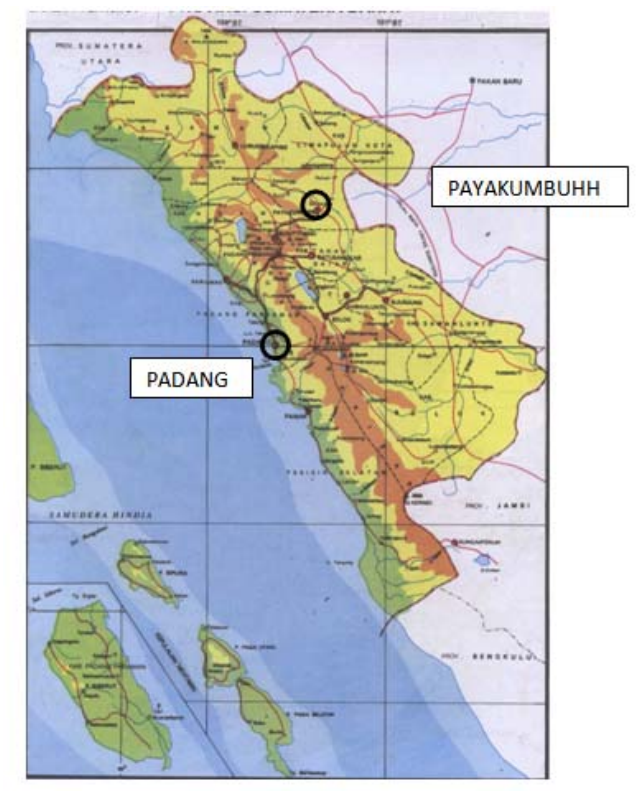

Gambar 1. Lokasi kota Payakumbuh dalam peta Sumatera Barat.

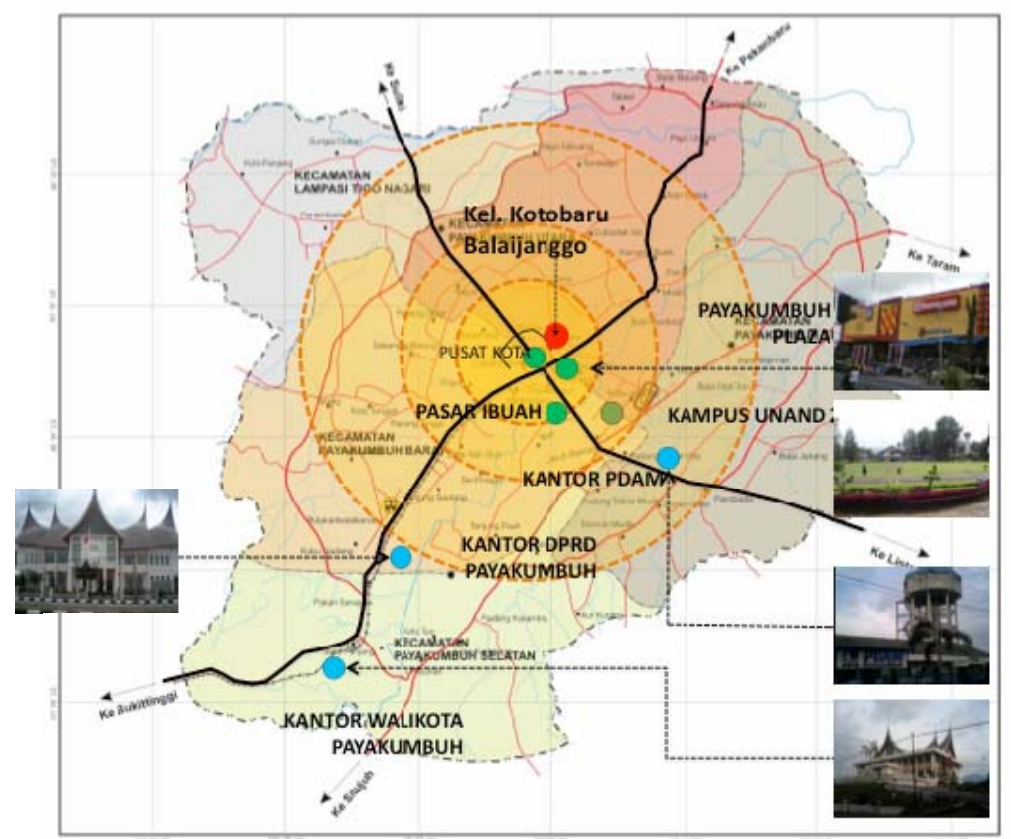

Gambar 2. Lokasi wilayah penataan di kelurahan Kotobaru Balaijanggo dalam peta kota Payakumbuh. 


\section{Tinjauan mengenai Tanah Ulayat di etnis Minangkabau}

Berbicara mengenai rumah tentu tidak akan lepas dari aspek tanah sebagai 'alas'- nya. Sejak nenek moyang manusia di jaman dahulu, tanah memang menempati posisi penting dalam kehidupan. Tanah tidak saja berperan sebagai tempat dimana manusia tinggal tapi juga sebagai tempat beraktivitas, tempat menyambung hidup. Bagi negeri agraris seperti Indonesia, tanah menempati posisi sangat penting untuk menunjang segala kehidupan masyarakatnya. Dari waktu ke waktu, kebutuhan untuk menguasai tanah semakin meningkat sejalan dengan kebutuhan akan 'alas' (tanah) yang terus meningkat sementara ketersediaan lahan yang terbatas tidak bertambah.

Karena keterbatasan itulah tanah menjadi masalah sensitif bagi manusia, juga berlaku bagi masyarakat etnis Minangkabau yang memandang tanah tidak saja sebagai sekedar tempat beraktivitas tetapi juga untuk menunjukan status sosial. Bagi orang minangkabau tanah dianggap sebagai salah satu kriteria yang menentukan martabat seseorang dalam kehidupan nagari. Seseorang yang memiliki tanah dianggap orang asli dalam nagari sehingga berhak atas kebesaran dalam nagari (Irwandi, 2010).

Selanjutnya menurut Irwandi (2010), hukum adat di Minangkabau menyatakan bahwa tidak ada sejengkalpun tanah yang tidak ada pemiliknya. Seberapapun luasnya pastilah ada penguasanya, baik oleh suatu kaum, suku maupun suatu nagari yang disebut dengan tanah ulayat. Tanah ulayat ini merupakan tanah yang dimiliki secara kolektif (bersama) dan bukan milik perorangan. Tanah ulayat merupakan milik suatu masyarakat ada. Tanah Ulayat juga sebagai pusaka sekaligus warisan leluhur masyarakat adat yang bersangkutan, dimanfaatkan untuk kesejahteraan anak kemenakan, sekaligus sebagai tanah cadangan bagi seluruh keturunan (garis ibu/matrilinial) yang akan bertambah terus di kemudian hari. Tanah Ulayat ini tidak bisa dipindahtangankan secara permanen kecuali dalam keadaan mendesak atas keputusan bersama (misalnya dibutuhkan dana untuk biaya penyelenggaraan mayat, biaya perkawinan, biaya perbaikan rumah gadang, biaya pesta pengangkatan penghulu). Namun, tanah ulayat milik suatu masyarakat adat dimungkinkan untuk dimanfaatkan oleh masyarakat adat lain, setelah ada persetujuan dari ketua dan seluruh masyarakat adat pemilik tanah dengan syarat yang ditentukan. Kondisi inilah yang kemudian memungkinkan suatu tanah ulayat memisahkan antara ‘alas' dengan bangunan yang ada di atasnya.

Dilihat dari aspek hukum tanah, pada prinsipnya ada dua macam hukum berkaitan dengan suatu tanah, yaitu asas terpisah horisontal dan asas melekat. Nah, tanah ulayat di Minangkabau menganut asas terpisah horisontal (Irwandi, 2010) yaitu terpisahnya tanah dengan apa yang ada diatasnya. Tanah ulayat dapat dimanfaatkan oleh seseorang ( yang bukan bagian dari masyarakat adat pemilik tanah tersebut) untuk tempat mendirikan bangunan, bahkan bangunan tersebut dapat disewakan ke pihak lain lagi, namun segala transaksi atas rumah tersebut tidak termasuk tanahnya. Karena tanah tersebut suatu saat harus kembali ke masyarakat adat pemilik tanah.

\section{Status Tanah Hunian Kumuh di Wilayah Penataan}

Pemerintah melalui program P2PKP-BK menunjuk wilayah kelurahan Kotobaru Balaijanggo sebagai salah satu lokasi yang mendapat program penataan hunian kumuh. Tidak semua wilayah kelurahan ini masuk dalam kategori hunian kumuh, namun ada beberapa spot dari wilayahnya yang ditempati oleh hunian kumuh. Kendala utama penataan hunian kumuh di wilayah ini adalah status tanah dimana hunian kumuh tersebut berdiri. Sebagian besar tanahnya merupakan tanah ulayat yang terlepas antara 'alas' dan bangunan-bangunan diatasnya. Wilayah ini memiliki luas 15 Ha terbagi atas tanah milik beberapa masyarakat adat. Sebagian tanah dimanfaatkan sendiri oleh anak kemenakan masyarakat adat yang bersangkutan dengan mendirikan rumah tempat mereka tinggal. Pada kondisi ini, penanganan lingkungan relatif mudah karena pemilik tanah dan bangunan adalah orang yang sama. 
Namun, terdapat kondisi yang berbeda pada sebagian tanah lain. Masyarakat adat pemilik tanah menyewakan tanah tersebut kepada pihak lain untuk jangka waktu tertentu. Pihak yang menyewa tanah tersebut diperbolehkan mendirikan bangunan diatasnya. Pada kondisi inilah terjadi perbedaan kepemilikan antara tanah dan bangunan diatasnya yang kemudian menyulitkan program penataan karena status kepemilikan yang berbeda tersebut. Kondisi menjadi lebih sulit ketika rumah yang dibangun kemudian disewakan lagi kepihak lain. Sehingga antara pemilik tanah, pemilik rumah dan penghuni rumah merupakan pihak-pihak yang berbeda.

Kondisi seperti ini jugalah yang menyebabkan munculnya lingkungan kumuh di wilayah ini karena rentang panjang antara penghuni rumah dengan tanahnya. Masyarakat yang mendirikan bangunan diatas tanah ulayat tersebut cenderung mendirikan bangunan seadanya saja, bukan bangunan permanen karena suatu saat akan meninggalkan tanah tersebut (jika masyarakat adat sebagai pemilik tanah tidak memperpanjang pemanfaatan tanah tersebut). Karena lokasi kelurahan ini di tengah kota, yang berarti dekat dengan pusat kegiatan ekonomi, tanah di sini pun memiliki nilai strategis secara ekonomi. Oleh karena itu, permintaan ruang untuk tempat tinggal pun tinggi sehingga banyak pemilik rumah di kelurahan ini kemudian membagi-bagi rumahnya untuk rumah sewaan. Dengan status kepemilikan tanah dan rumah yang berbeda-beda, penghuni rumah semakin acuh dengan kondisi rumah dan lingkungannya, bagi penyewa yang penting adalah sewa tempat tinggal yang murah tanpa memikirkan kenyamanan dan keindahan, penghuni tidak memiliki sense of belonging, baik kepada bangunan tempat tinggalnya maupun kepada lingkungannya karena mereka hanya sekedar tidur. Di sisi lain, pemilik tanah juga cenderung acuh dan lepas tangan karena penggunaan tanah sudah diberikan kepada pihak ketiga dan bangunan apapun yang didirikan di atasnya menjadi tanggung jawab penyewa tanah tersebut.

Situasi seperti ini lah yang mendominasi hunian di kelurahan Kotobaru Balaijanggo. Lokasinya yang berada dipusat kota menjadikan lokasi disini sangat strategis. Keberadaan pasar Payakumbuh yang berada tidak jauh menjadikan lokasi ini diminati para pedagang untuk tinggal yang umumnya merupakan masyarakat golongan menengah ke bawah. Mereka menikmati tinggal di wilayah ini karena dekat dengan pasar, tempat beraktivitas sehari-hari, dan tersedianya rumah-rumah kontrakan murah yang sesuai dengan kemampuan ekonominya walaupun dengan kondisi tidak layak (Gambar 3).

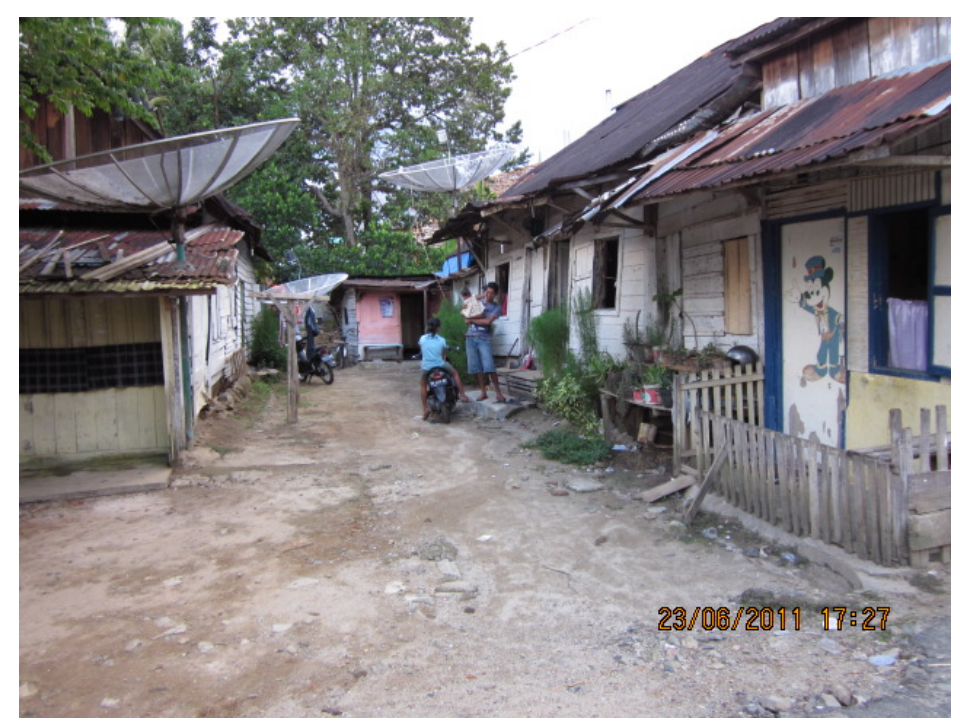

Gambar 3. Kondisi umum beberapa rumah-rumah yang berada di atas tanah sewaan. 


\section{Kondisi Bangunan Tidak Layak dan Konsep Penanganannya Berkaitan dengan Status Tanah Ulayat}

Kondisi bangunan/rumah kumuh di wilayah ini memang cukup memprihatinkan. Secara umum, bentuk rumah-rumah tersebut dapat dikategorikan menjadi rumah tunggal dan rumah deret. Kondisi keduanya banyak yang tidak layak huni, terlebih lagi bagi rumah deret yang paling mendominasi kekumuhan di wilayah ini.

Umumnya luasan unit hunian rumah deret sangat sempit, dengan ukuran 3m x 5m dihuni lebih dari 4 orang. Seluruh kegiatan rumah pun harus ditampung didalamnya seperti tempat tidur, makan, masak, MCK. Oleh karena itu aktivitas keseharian penghuni sering akhirnya 'luber' keluar rumah (Gambar 4). Kualitas bangunan juga sangat memprihatinkan, sirkulasi udara yang tidak sehat dengan jendela kecil dan tanpa cross ventilation menciptakan ruang dalam yang lembab dan pengap, asap dapur yang memenuhi seluruh rumah ketika penghuni sedang masak, cahaya alami yang minim sehingga suasana didalam rumah tampak selalu gelap meskipun siang hari (Gambar 5). Jangan lagi berbicara tentang keanyamanan seperti ruang duduk berkumpul dengan keluarga, atau ruang belajar bagi anak yang cukup cahaya baik siang atau malam hari, untuk kondisi dasar sebagai tempat/rumah untuk istirahat tidur pun kurang memadai mengingat sempitnya rumah.

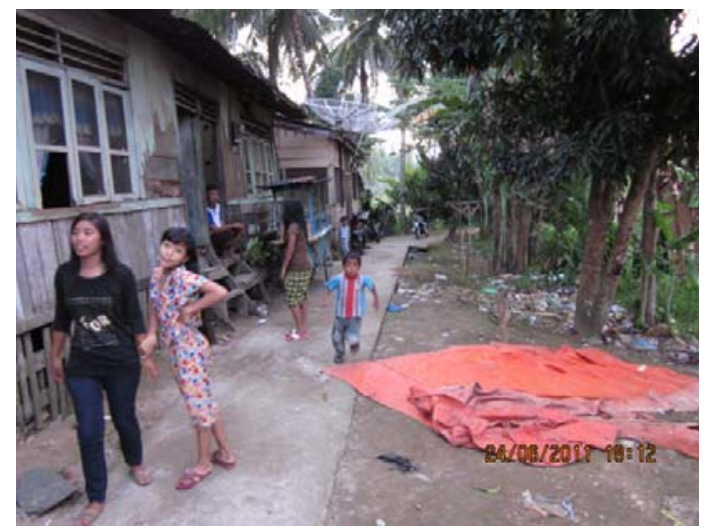

Gambar 4. Rumah deret yang sempit sehingga aktivitas keseharian penghuni 'luber’ ke jalan.

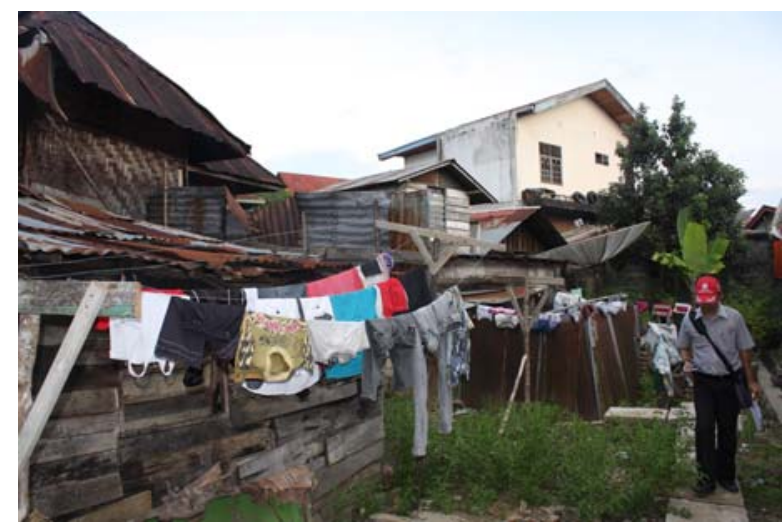

Gambar 5. Kondisi beberapa rumah yang tidak layak dengan jendela yang mini, material bangunan yang campur aduk.

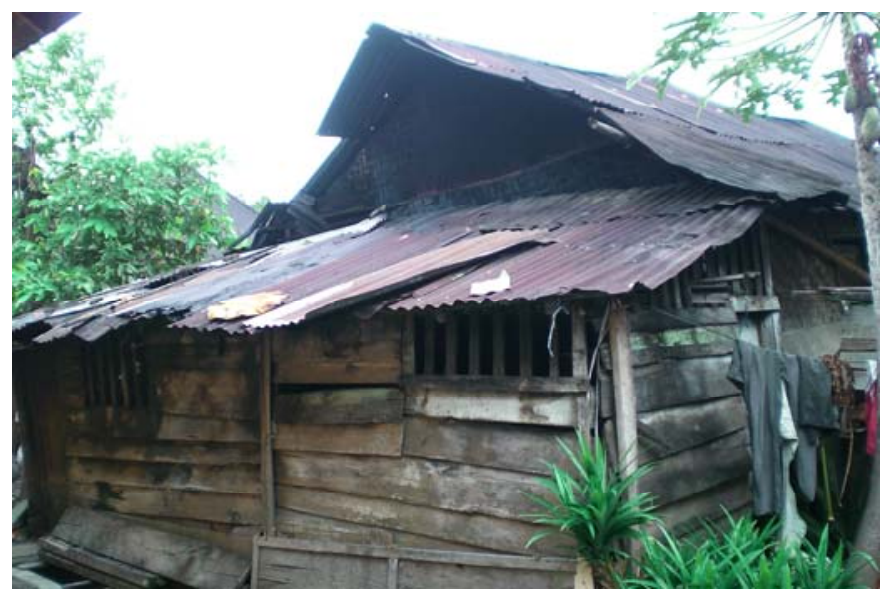

Gambar 6. Kondisi rumah yang memprihatinkan dengan dinding yang hampir roboh. 
Rumah-rumah tersebut umumnya berdinding kayu dengan atap seng. Beberapa rumah memiliki dinding kombinasi antara bata dan kayu. Hampir semua bangunan tersebut memiliki dinding kayu yang sudah keropos, kayu-kayu yang sudah tidak utuh lagi sehingga lembab dan 'tertembus' angin (Gambar 6). Kondisi ini tentu tidak sehat bagi penghuni didalamnya. Bahkan ada beberapa rumah yang masih berlantaikan tanah tanpa ubin/keramik. Beruntung wilayah ini mendapat bantuan MCK komunal, sehingga meskipun banyak rumah deret yang tidak memiliki kamar mandi sendiri namun penghuninya mendapatkan 'kemewahan' dalam hal mandi dan cuci tersebut.

Melihat kondisi rumah yang sangat memprihatinkan sebagaimana dijelaskan diatas, memang sudah sepantasnya kualitas lingkungan dan rumah-rumah tersebut mendapat bantuan untuk diperbaiki. Namun pemerintah melalui program PLP2K-BK ini kesulitan melaksanakan bantuan penataan lingkungan khususnya yang berkaitan dengan perbaikan rumah-rumah kumuh yang ada tersebut karena status rumah dan tanah yang berbeda pemilik. Sesuai peraturan, pemerintah hanya dapat memberikan bantuan perbaikan pada rumah yang 'alas' tanahnya berstatus milik sedangkan kondisi yang ada di lokasi tersebut adalah didalam petak yang sama namun pemilik rumah dan pemilik tanah berbeda. Kondisi ini jelas menutup kemungkinan bantuan pemerintah untuk perbaikan rumah-rumah kumuh karena kepemilikan rumah dan tanah harus pada pihak yang sama.

Meskipun tidak layak huni, permintaan rumah-rumah sewaan tersebut tetap tinggi. Umumnya penyewa adalah masyarakat berpenghasil rendah (MBR). Hal ini menunjukan tingginya kebutuhan hunian murah yang dekat dengan pusat kota. Oleh karena itu, penataan/perbaikan rumah untuk meningkatkan kualitas rumah jangan sampai akhirnya menghilangkan kemampuan MBR untuk menyewa rumah di wilayah ini.

\section{Solusi Penataan Hunian Kumuh yang Direkomendasikan}

Ada beberapa solusi yang dapat ditempuh. Pertama, melibatkan masyarakat adat pemilik tanah ulayat, agar program perbaikan rumah ini dapat turun sehingga hubungan yang terjadi adalah antara pemerintah dan pemilik tanah (meskipun rumah yang akan diperbaiki dimiliki oleh si penyewa tanah ulayat tersebut). Kedua, melibatkan pemimpin masyarakat adat yang bersangkutan karena keputusan atas tanah ulayat harus atas pengetahuan masyarakat adat melalui pemimpinnya tersebut. Ketiga, perbaikan rumah melibatkan baik penghuni rumah (penyewa tanah dan/atau rumah) dan pemilik tanah. Keempat, pemilik tanah ulayat harus dimintai persetujuannya, bahwa rumah yang ada di atasnya (yang dikuasai oleh pihak ketiga) akan diperbaiki dan dapat juga disepakati bahwa tidak akan ada perubahan kerjasama antara mereka setelah rumah diperbaiki. Ketika rumah sudah baik, bisa saja pemilik tanah kemudian merubah kerjasama dan menaikan harga sewa tanahnya. Kelima, penataan hunian kumuh tersebut dilakukan dalam kerangka peremajaan kawasan, tidak saja dilakukan perbaikan rumah-rumah yang tidak layak tersebut tapi juga peningkatan infrastruktur (PSU) lainnya sehingga peningkatan kualitas lingkungan dapat dirasakan oleh sebanyak-banyaknya warga kelurahan tersebut dan warga kota Payakumbuh.

\section{KESIMPULAN}

Penataan kawasan hunian kumuh merupakan salah satu program pemerintah untuk meningkatkan kualitas suatu lingkungan, salah satu programnya dilaksanakan oleh Kementerian Negara Perumahan Rakyat. Tahun 2011, program PLP2K-BK menunjuk kawasan kumuh di kelurahan Kotobaru Balaijanggo, kota Payakumbuh sebagai salah satu wilayah penataannya. Namun dalam penataannya terdapat kendala mendasar berkaitan dengan status 'alas' (tanah) dimana bangunan/rumah kumuh yang hendak diperbaiki tersebut berada. Rumah-rumah kumuh tersebut sebagian besar diatas tanah Ulayat yang disewakan kepada warga yang bukan anggota masyarakat adat pemilik tanah. 
Bahkan ada rumah yang dibangun oleh penyewa tanah tersebut, sehingga pemilik tanah dan pemilik rumah merupakan pihak yang beda. Pada satu sisi, kondisi sebagian besar rumah-rumah diatas tanah ulayat tersebut sangat memprihatinkan dan layak untuk diperbaiki. Namun di sisi lain, program pemerintah tidak dapat menjangkau rumah yang beda kepemilikan dengan 'alas'nya. Oleh karena itu, pendekatan yang dilakukan adalah dengan melibatkan masyarakat adat pemiliki tanah ulayat, meskipun memerlukan waktu yang lebih panjang karena harus melibatkan seluruh masyarakat adat pemiliki tanah.

Selanjutnya, berkaitan dengan banyaknya MBR yang tinggal di wilayah penataan karena berada di pusat kota, maka perbaikan rumah/bangunan nantinya jangan sampai 'memutus' kemampuan MBR untuk dapat tinggal di tempat tersebut. Jangan sampai sewa tanah menjadi mahal setelah lingkungan menjadi lebih baik. Oleh karena itu, setelah adanya perbaikan bangunan harus ada kesepakatan dengan pemilik tanah bahwa tidak ada kenaikan harga sewa tanah untuk jangka waktu tertentu.

\section{DAFTAR PUSTAKA}

Irwandi. (2010). Pergeseran Hukum Adat dalam Pemanfaatan Tanah Ulayat Kaum di Kecamatan Banu Hampu Kabupaten Agam Provinsi Sumatera Barat. Semarang: Program Pasca Sarjana Universitas Diponegoro.

Pemerintah Kota Payakumbuh. (2011). Jarak antara Kota Payakumbuh ke Kota Dalam Propinsi dan ke Propinsi Riau (Km). Diakses dari http://www.payakumbuhkota.go.id/?lang=ina\&action=download\&type=statistik\&stipe=sta\&i dgrup $=12$

Pemerintah Kota Payakumbuh. (2011). Letak Gegrafis Kota Payakumbuh. Diakses dari http://www.payakumbuhkota.go.id/?lang=ina\&action=download\&type=statistik\&stipe=sta\&i dgrup $=12$

Pemerintah Kota Payakumbuh. (2011). Luas Kabupaten dan Kota di Sumatera Barat. Diakses dari http://www.payakumbuhkota.go.id/?lang=ina\&action=download\&type=statistik\&stipe=sta\&i dgrup $=12$

RI. (2011). Undang-Undang Republik Indonesia no. 1 tahun 2011 tentang Perumahan dan Kawasan Permukiman. Jakarta: Kementerian Perumahan Rakyat.

Soehendera, Djaka. (2010). Sertifikat Tanah dan Orang Miskin, (edisi pertama). Jakarta: HuMa. 